Article

\title{
Study of the Microstructure and Ring Element Segregation Zone of Spray Deposited $\mathrm{SiC}_{\mathrm{p}} / 7055 \mathrm{Al}$
}

\author{
Hao Yang ${ }^{1}$, Xin-wei She ${ }^{1,2}$, Bin-bin Tang ${ }^{1}$, Chun-mei Li ${ }^{1}$ and Xian-quan Jiang ${ }^{1,2, *}$ \\ 1 Faculty of Materials and Energy, Southwest University, Chongqing 400715, China; \\ yanghaolouis@163.com (H.Y.); 13983073429@163.com (X.-w.S.); 2013990014@qhu.edu.cn (B.-b.T.); \\ lcm1998@swu.edu.cn (C.-m.L.) \\ 2 Chongqing Advanced Materials Research Center, Chongqing Academy of Science and Technology, \\ Chongqing 401123, China \\ * Correspondence: jsq89@swu.edu.cn
}

Received: 7 March 2019; Accepted: 4 April 2019; Published: 20 April 2019

\begin{abstract}
Composites of 7055 aluminum (Al) matrix reinforced with $\mathrm{SiC}$ particles were prepared using the spray deposition method. The volume fraction of the phase reinforced with SiC particles was $17 \%$. The effect of the introduction of SiC particles on the deposited microstructure and properties of the composites was studied in order to facilitate the follow-up study. The structure and element enrichment zone of spray-deposited $\mathrm{SiC}_{\mathrm{p}} / 7055 \mathrm{Al}$ matrix composites were studied by Optical Microscope (OM), X-ray diffraction (XRD), Scanning Electronic Microscopy (SEM) and Transmission electron microscopy (TEM). The results show that the reinforcement phases of the SiC particles were uniformly distributed on the macro and micro levels, and a few $\mathrm{SiC}$ particles were segregated into annular closed regions. $\mathrm{C}$ and $\mathrm{Si}$ on the surface of $\mathrm{SiC}$ particles diffused to the $\mathrm{Al}$ matrix. The distribution of the two elements was gradient weakening with $\mathrm{SiC}$ particles as the center, and the enrichment zones of $\mathrm{Si}, \mathrm{Mg}$ and $\mathrm{Cu}$ formed in the middle of the closed annular area of a few $\mathrm{SiC}$ particles. The enrichment zones were mainly composed of alpha- $\mathrm{Al}, \mathrm{SiC}, \mathrm{Al}_{2} \mathrm{CuMg}, \mathrm{Al}_{2} \mathrm{Cu}$ and $\mathrm{MgZn}_{2} . \mathrm{AlCu}$ and $\mathrm{AlMgCu}$ phase precipitate on the surface of the $\mathrm{SiC}$ particles, beside the particle boundary, and had the characteristics of preferred nucleation. They tended to grow at the edges and corners of $\mathrm{SiC}$ particles. It was observed that the formation of nanoparticles in the alloy had a pinning effect on dislocations. The different cooling rates of the $\mathrm{SiC}$ particles and the $\mathrm{Al}$ matrix led to different aluminum liquid particle sizes, ranging from 20 to $150 \mu \mathrm{m}$. In the region surrounded by $\mathrm{SiC}$ particles, the phenomenon of large particles extruding small particles was widespread. Tearing edges and cracks continued to propagate around the $\mathrm{SiC}$ particles, increasing their propagation journey and delaying the fracture of the materials.
\end{abstract}

Keywords: spray deposition; 7055 aluminum alloy; $\mathrm{SiC}$ particles; diffusion; element segregation

\section{Introduction}

As-cast materials with a uniform composition, fine structure and high density can be obtained by spray deposition technology [1,2]. This technology has been widely used in the development of and research into aerospace alloys and high-performance military materials [3-8]. SiC particle reinforcement has the advantages of a simple process and low production cost. The reinforced material has the characteristics of high specific strength, high specific stiffness and a good thermal expansion coefficient [9-16]. Scholars at home and abroad have made high-strength aluminum-gold materials or $\mathrm{SiC}_{\mathrm{p}} / \mathrm{Al}$ metal composites by spray deposition or other methods, and have studied how to use them as lightweight structural materials in weapons manufacturing and military radar packaging [17-22]. 
$\mathrm{SiC}$ particles, particle size, and the second phase are important factors affecting the mechanical properties of $\mathrm{SiC}_{\mathrm{p}} / 7055 \mathrm{Al}$ matrix composites. A large number of studies have shown that $\mathrm{SiC}$ particles can bear part of the load, influence the microstructure, and reduce the crack growth ability of the hard phase [23-26], but the pore between the enriched SiC particles will become the channel of crack growth [27]. The mechanical properties of spray-deposited composites decrease gradually due to the large particle size [28]. The second phase particles in composites are mainly $\mathrm{MgZn}_{2}$ and $\mathrm{CuAl}_{2}$, which can reduce the precipitation of the second phase and increase the solid solubility, and greatly improve the hardness of the composites [29].

At present, the preparation methods of particulate reinforced aluminum matrix composites mainly include the stirring casting method and the melt infiltration method, the advection casting method, the powder metallurgy method and the spray deposition method. Because the cooling rate of the stirring casting method and the melt infiltration method is low, the distribution of reinforcement particles is uneven, and the properties of the prepared materials are poor. The properties of composites obtained by advection casting and powder metallurgy are higher, but there are some problems such as degassing difficulty, structure coarsening and complex technology. SiC particulate-reinforced aluminum matrix composites prepared by spray deposition technology have the advantages of high Young's modulus and good wear resistance [30]. Compared with traditional methods, spray deposition technology has the advantages of a simple process, low segregation, a high cooling rate, and a fine microstructure. It has become one of the common methods used to prepare aluminum matrix composites [31,32]. The development of spray deposition technology is restricted by the existence of micro-holes in ingots prepared by spray deposition, and the incomplete metallurgical bonding between particles and layers. Many scholars have adopted extrusion and rolling methods to improve the density and material properties of composites [33-35]. The research on materials with SiC particle-reinforced phases is mostly focused on the subsequent thermal deformation and treatment process, and there is less research on deposited $\mathrm{SiC}$ particles, aluminum liquid particles, second phase and $\mathrm{SiC}$ particle-collective interface.

In this study, 7055 aluminum alloy with excellent properties was combined with spray deposition technology, and a new aluminum matrix composite was prepared by adding $17 \%$ of $\mathrm{SiC}$ particle-reinforced phase. The enrichment zones of $\mathrm{Mg}$, $\mathrm{Si}$ and $\mathrm{Cu}$ in the annular $\mathrm{SiC}$ particles were observed; these have not previously been reported in the literature. The formation mechanism of the enrichment zones and the effect of the $\mathrm{SiC}$ particles on the microstructure and properties of the deposited $\mathrm{SiC}$ particles were also studied.

\section{Experiment}

$\mathrm{SiC}_{\mathrm{p}} / 7055$ aluminum matrix composites were prepared by spray deposition. The chemical composition of 7055 alloy is shown in Table 1 . Before use, the particles were heated at $250{ }^{\circ} \mathrm{C}$ for 10 $\mathrm{h}$ to remove the crystalline water and adsorbents, thus reducing the agglomeration of $\mathrm{SiC}$ particles themselves. The spray deposition process parameters are shown in Table 2. The volume fraction of added alpha-SiC particles was $17 \%$, and the density of the material was $92.3 \%$. The deposited ingots with $160 \mathrm{~mm}$ diameter and $320 \mathrm{~mm}$ height were prepared by spray deposition. The samples with $140 \mathrm{~mm}$ diameter and $310 \mathrm{~mm}$ height were obtained by turning. The surface of the ingot was sampled along the radial direction as shown in Figure 1. The ZEISS Axiovert 200MAT metallographic microscope (ZEISS, Oberkochen, Germany) was used to observe the aluminum liquid particle structure and $\mathrm{SiC}$ particle distribution of the composites. Scanning electron microscopy was used to observe the microstructure and fracture morphology, and phase analysis was carried out by an energy dispersive spectrometer (EDS). X-ray diffraction was used to identify the type of phase and transmission electron microscopy was used to observe the pinning effect of nanoparticles on dislocations.

Table 1. Nominal composition of 7055 aluminum alloy.

\begin{tabular}{ccccccccccc}
\hline Element & Si & Fe & Cu & Mn & Mg & Cr & Zn & Ti & Zr & Al \\
\hline Content $(\%)$ & 0.1 & 0.15 & $2.0-2.6$ & 0.05 & $1.8-2.3$ & 0.4 & $7.6-8.4$ & 0.06 & $0.08-0.25$ & Other \\
\hline
\end{tabular}


Table 2. Spray deposition process parameters.

\begin{tabular}{ccc}
\hline Experimental Parameters & Numerical Value & Unit \\
\hline Atomization temperature & $750 \sim 850$ & ${ }^{\circ} \mathrm{C}$ \\
Nebulizer pressure & $0.6 \sim 0.8$ & $\mathrm{MPa}$ \\
Diameter of sedimentary disk & 530 & $\mathrm{~mm}$ \\
Matrix rotation speed & $150 \sim 250$ & $\mathrm{r} / \mathrm{min}$ \\
Powder-feeding pressure & $0.1 \sim 0.2$ & $\mathrm{MPa}$ \\
\hline
\end{tabular}
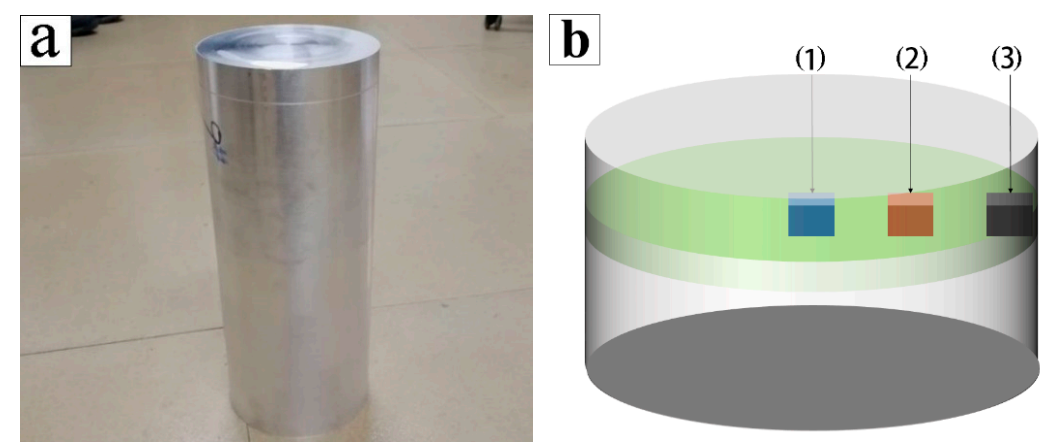

Figure 1. Macroscopic morphology and sampling location of spray-deposited $\mathrm{SiC}_{\mathrm{p}} / 7055$ aluminum composites: a: sample macroscopic morphology, b: sampling location diagram: (1) at the center, (2) at the center of the radius, (3) at the edge.

\section{Results and Analysis}

\subsection{Metallographic Microstructure Analysis}

As shown in Figure 1a, samples were taken at different locations and orientations of deposited $\mathrm{SiC}_{\mathrm{p}} / 7055 \mathrm{Al}$ composites by spray deposition. At the same height from the bottom of the sample, the radial metallographic images of the center of the cross-section (Figure $1 b(1)$ ), the center of the radius of the cross-section (Figure $1 b(2)$ ), and the edge of the cross section (Figure $1 b(3)$ ) were compared.

Figure 2 shows the metallographic structure of spray-deposited $\mathrm{SiC}_{\mathrm{p}} / 7055 \mathrm{Al}$ matrix composites at different locations. From Figure $2 \mathrm{a}-\mathrm{c}$, it can be observed that the microstructures of the composites at different positions were fine and uniform. The $\mathrm{SiC}$ particles were about $40-50 \mu \mathrm{m}$ in size. They were uniformly distributed in the matrix macroscopically, segregated in the micro-region, and closed annular in a few places. In previous studies, spray-deposited $\mathrm{SiC}_{\mathrm{p}} / 7055$ aluminum alloy had a very similar metallographic structure at different locations at the same height. The aluminum liquid particle size was equiaxed and uniform. The main particle size was $40 \sim 50 \mu \mathrm{m}$ [36]. Figure $2 \mathrm{~d}-\mathrm{f}$ shows the particle structure of the 7055 alloy at different locations after introducing SiC particles. The three metallographic structures were similar, and the aluminum liquid particle sizes were quite different, basically between 20 and $150 \mu \mathrm{m}$. When the $\mathrm{SiC}$ particles distribute evenly in the micro-segregation region, there will be fine and uniformly distributed particle distribution regions in these $\mathrm{SiC}$ particle segregation regions. The aluminum liquid particle size was between 10 and $50 \mu \mathrm{m}$, which was smaller than that of the 7055 aluminum alloy sprayed without the $\mathrm{SiC}$ particle reinforcement phase. In the region far away from the $\mathrm{SiC}$ particles, there were aluminum liquid particles of size $100-200 \mu \mathrm{m}$. Because of the addition of the $\mathrm{SiC}$, the cooling rate of the $\mathrm{SiC}$ particles was relatively fast during the solidification process, and there were a large number of active sites on the surface, which can create conditions for a large amount of nucleation of aluminum liquid particles. Therefore, a large number of $\mathrm{SiC}$ particles first nucleated in the $\mathrm{SiC}$ segregation zone and at the interface between the $\mathrm{SiC}$ and the matrix, and the number of particles was further away from the $\mathrm{SiC}$ region. However, due to the limited space, the particles near the $\mathrm{SiC}$ particles needed space and alloy composition to grow. After nucleation, the particles inhibited each other's particle growth. On the other hand, the SiC particles hindered the direction of the particle growth. When the particles in the SiC segregation region met $\mathrm{SiC}$ 
particles in the process of particle growth, the particle boundary ceased to migrate and the particles stopped growing in that direction in the SiC segregation region. A large number of small and uniform particles were formed near the particles. After the formation of nuclei far from the SiC particles, the size of the nuclei was larger because of the high temperature, sufficient energy, alloy composition, and growth space.
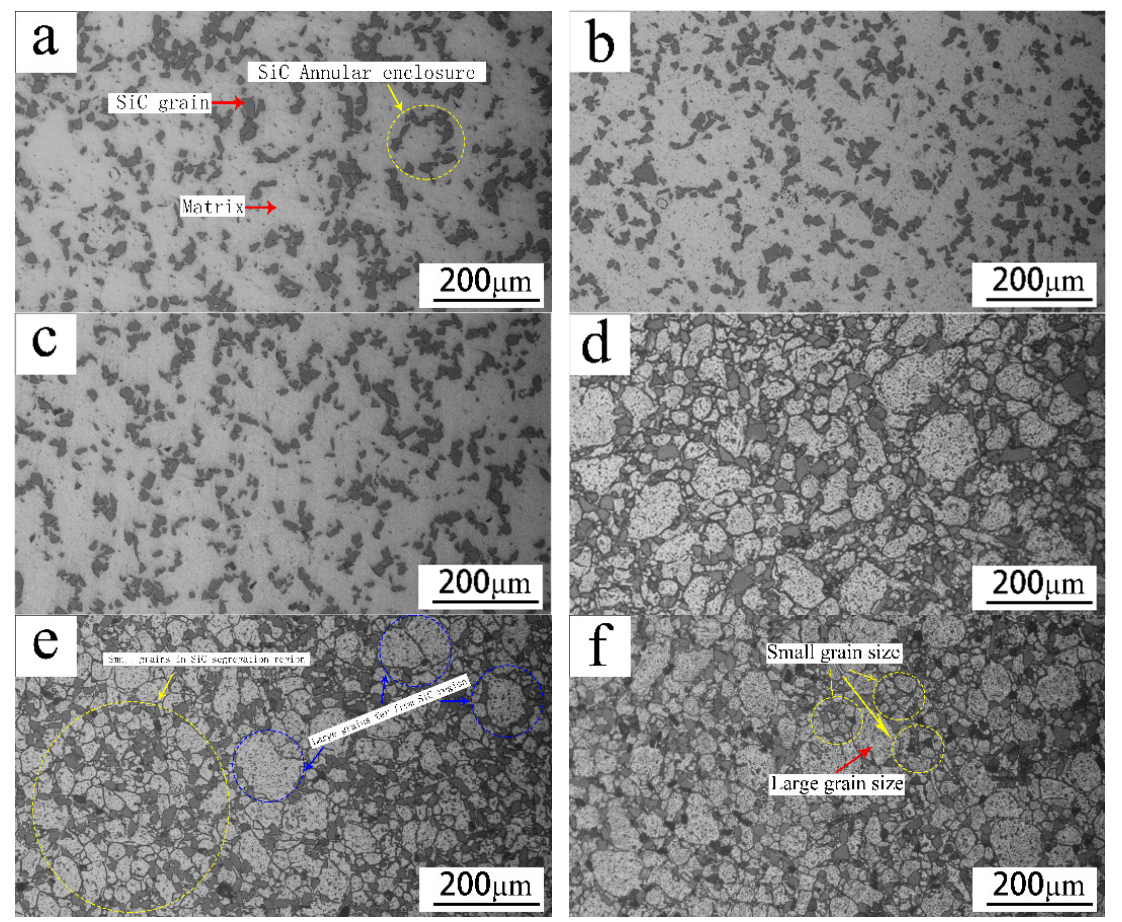

Figure 2. Metallographic structure of spray-deposited $\mathrm{SiC}_{\mathrm{p}} / 7055 \mathrm{Al}$ composites at different locations: $(\mathbf{a}-\mathbf{c})$ were deposited at different locations, and $(\mathbf{d}-\mathbf{f})$ are particle structures at the corresponding locations.

\subsection{Microstructure Analysis}

Figure 3 shows the XRD pattern of the composite. Samples were tested and analyzed on a Shimadzu XRD-6100 X-ray diffractometer (Shimadzu, Kyoto, Japan). The scanning power was $4 \mathrm{~kW}$, the scanning angle was $10-90^{\circ}$, and the scanning speed was $2^{\circ} / \mathrm{min}$. The analysis shows that the alloys in the composites were composed of alpha- $\mathrm{Al}, \mathrm{SiC}, \mathrm{Al}_{2} \mathrm{CuMg}, \mathrm{Al}_{2} \mathrm{Cu}$ and $\mathrm{MgZn}_{2}$. The reinforcing phase was hexagonal crystalline alpha-SiC, and the content of $\mathrm{MgZn} 2$ was higher in the second phase.

(a)

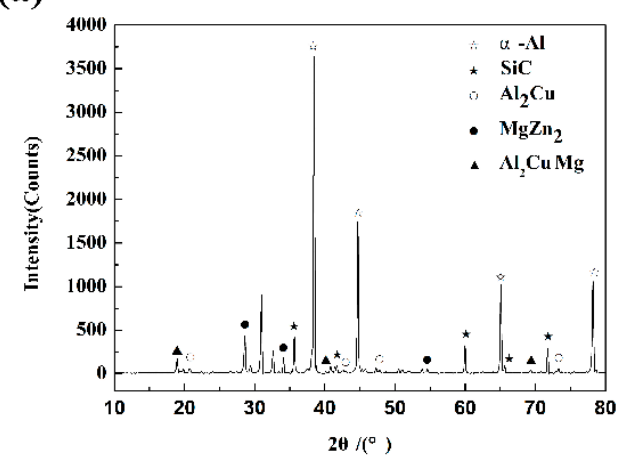

(b)

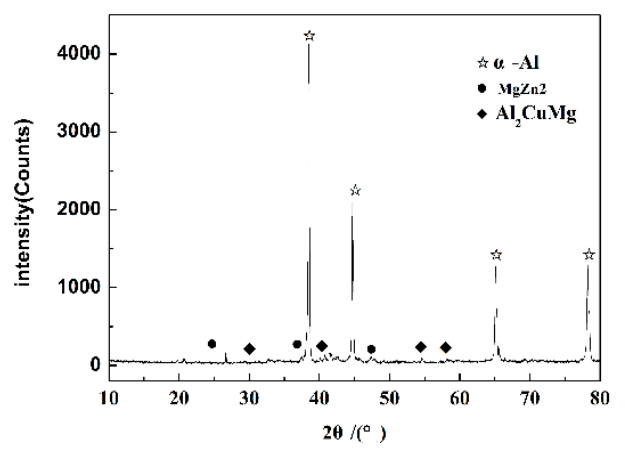

Figure 3. XRD analysis of spray-deposited $\mathrm{SiC}_{\mathrm{p}} / 7055 \mathrm{Al}$ matrix composites and $7055 \mathrm{Al}$ matrix: (a) $\mathrm{SiCp} / 7055 \mathrm{Al}$ matrix composites (b) $7055 \mathrm{Al}$ matrix. 
A JSM-6610 scanning electron microscope (JEOL, Tokyo, Japan) was used to observe the microstructure of the experiment. The scanning voltage was $20 \mathrm{kV}$. Component analysis was performed using an Oxford Energy Spectrometer (Oxford instruments, Oxford, UK). Figure 4 is a scanning electron microscopic image of the microstructures of the composites. From Figure 4a, it can be observed that the $\mathrm{SiC}$ was segregated locally (circles indicate the aggregation distribution, and arrows indicate voids), and there were voids near the junction of the larger $\mathrm{SiC}$ particles and the matrix and in the $\mathrm{SiC}$ segregation region. Because of the poor wettability and poor bonding strength between the $\mathrm{SiC}$ particles and the aluminum matrix, voids were formed at the interface. From Figure $4 b$, it can be seen that there were a large number of dispersed particles in the matrix of the composite material. The second phase of the dispersed particles in the matrix of the composite material was measured by EDS. The results are shown in Table 3. According to the related literatures and the XRD analysis, the $\mathrm{AlCu}$ and $\mathrm{AlCuMg}$ phases precipitated on the particle boundary and the $\mathrm{SiC}$ particle surface. Through further observation and analysis, it was found that the $\mathrm{AlCu}$ and $\mathrm{AlMgCu}$ phases that precipitated on the surface of the $\mathrm{SiC}$ particles also had the characteristics of preferred nucleation, and they tended to grow on the particle boundary and at the edges and corners of the SiC particles.

Table 3. EDS test results (wt.\%).

\begin{tabular}{cccccccc}
\hline Number & Second Phase & Al & Zn & Mg & $\mathbf{C u}$ & $\mathbf{S i}$ & $\mathbf{C}$ \\
\hline 1 & Al matrix & 91.1 & 6.4 & 0.9 & 2.5 & 0 & 0 \\
2 & Al matrix near SiC & 75.7 & 5.7 & 0 & 1.2 & 7.3 & 10.1 \\
3 & Al matrix far from SiC & 84.6 & 5.5 & 0 & 1.3 & 0 & 8.6 \\
4 & SiC & 0 & 0 & 0 & 0 & 67.4 & 32.6 \\
5 & AlMgCu phase & 46.5 & 3.6 & 15 & 9.8 & 18.2 & 0 \\
6 & AlCu phase & 59.8 & 3 & 0 & 36 & 1.2 & 0 \\
\hline
\end{tabular}

In Table 3, it can be seen that the $\mathrm{C}$ and $\mathrm{Si}$ contents near the $\mathrm{SiC}$ particles were higher than those of the $\mathrm{Al}$ matrix. The farther away from the SiC particles, the lower the content of $\mathrm{C}$ and $\mathrm{Si}$. Figure $4 \mathrm{~d}$ shows a line scan near the $\mathrm{SiC}$ particles.

During the deposition process, the environment temperature of the composites was relatively high. SiC particles react with $7055 \mathrm{Al}$ droplets after atomization. A part of the formed Si diffused into the $7055 \mathrm{Al}$ matrix. At the same time, the surface of $\mathrm{SiC}$ dissolved to form $\mathrm{Si}$ and $\mathrm{C}$ that diffused to the matrix [37,38], forming the gradient region of $\mathrm{Si}$ and $\mathrm{C}$ shown by EDS midline scanning.

Figure 4f,h,i are elemental surface scanning maps of $\mathrm{Si}, \mathrm{Mg}$ and $\mathrm{Cu}$ in the closed region of the $\mathrm{SiC}$ particle group. From these maps, as well as Figure 4e, it can be seen that there was a segregation region with a staggered distribution of $\mathrm{Si}, \mathrm{Mg}$ and $\mathrm{Cu}$ precipitates and matrix-like phases in the closed region of the $\mathrm{SiC}$ particle group. EDS analysis of the element-enriched phase and matrix-like phase showed that the proportion of $\mathrm{Si}, \mathrm{Mg}$ and Cu elements in the precipitated phase were $1260 \%, 1210 \%$ and $715 \%$ higher than that of the matrix-like phase in the annular sealing zone of the SiC particles, and $21670 \%, 880 \%$ and $457 \%$ higher than that of the 7055 alloy respectively.

In this study, the diffusion of $\mathrm{SiC}$ particles reacting with the matrix and dissolving into the matrix followed non-oriented selective free diffusion. However, the EDS surface scan results showed that the diffusion of the Si elements in the annular enclosure region followed oriented selective diffusion, (see Table 4). The diffusion direction of the Si elements in the region was from the outside to the inside of the annular $\mathrm{SiC}$ particle group, and finally, in the annular enclosure region. A new segregation region of $\mathrm{Mg}$, Si and $\mathrm{Cu}$ elements formed in the center, but this phenomenon was not seen in other regions. This was due to the formation of $\mathrm{Mg}$ and $\mathrm{Cu}$ segregation zones in the matrix of this region during spray deposition, which resulted in the orientation-selective diffusion of $\mathrm{Si}$ elements. From Figure $4 \mathrm{f}, \mathrm{h}-\mathrm{j}$, it can be seen that the enrichment zones of $\mathrm{Mg}$, $\mathrm{Si}$ and $\mathrm{Cu}$ had obvious phase boundaries with the matrix. During the deposition process, the deposited billet was in a high temperature environment, thus the $\mathrm{Si}$ element was able to be fully diffused and tended to diffuse to the enrichment zones of $\mathrm{Mg}$ and $\mathrm{Cu}$, forming a new segregation zone. 

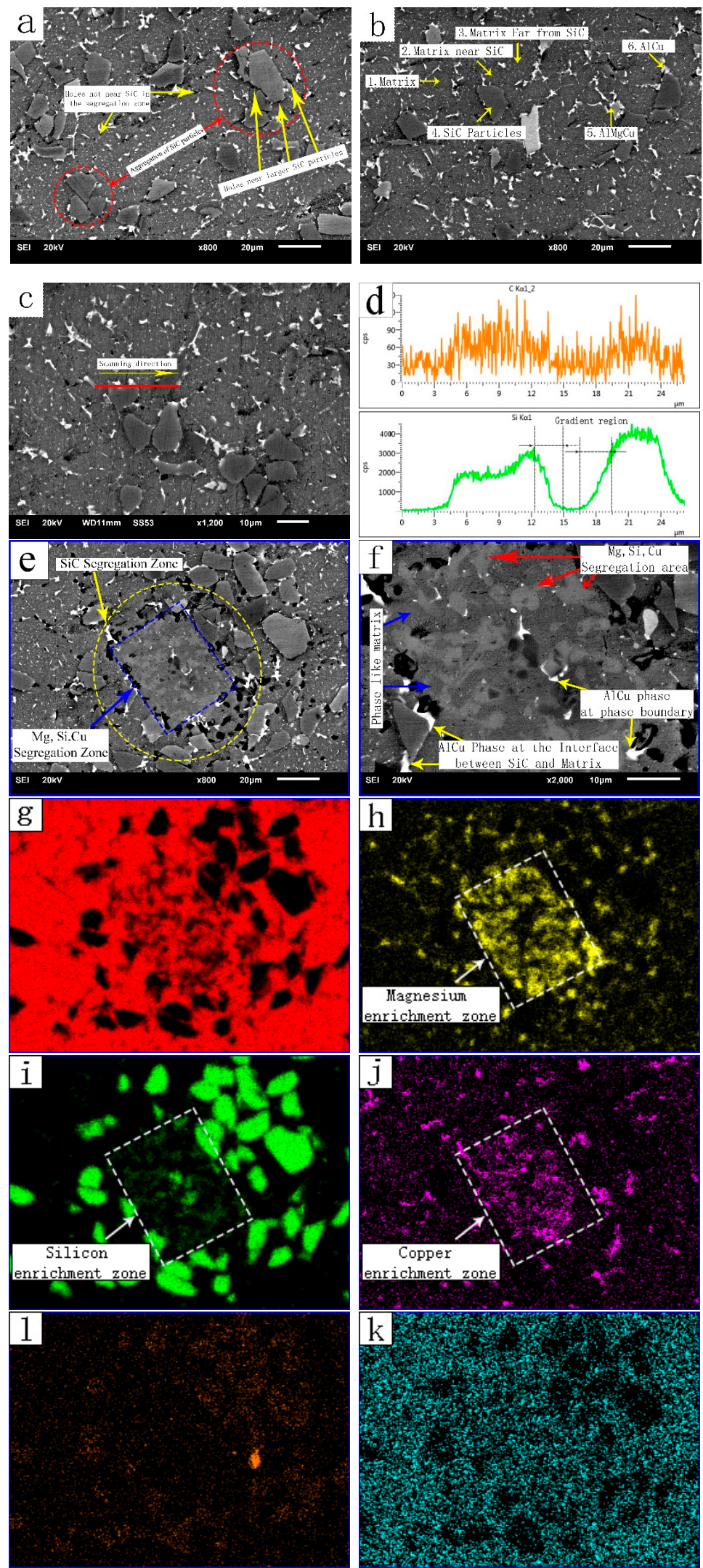

Figure 4. Scanning electron microscopy photos of spray-deposited $\mathrm{SiC}_{\mathrm{p}} / 7055 \mathrm{Al}$ matrix composites: $(\mathbf{a}, \mathbf{b})$ scanning image; (c) line scanning image; (d) line scanning distribution of $\mathrm{C}$ and Si elements in (c); (e) annular closed area scanning image; (f) enlarged area map of (e); (g-k) elemental distribution maps of $\mathrm{Al}, \mathrm{Mg}, \mathrm{Si}, \mathrm{Cu}, \mathrm{C}$ and $\mathrm{Zn}$, respectively. 
Table 4. EDS test result for the annular closed zone (wt.\%).

\begin{tabular}{ccccc}
\hline Test Location & $\mathbf{S i}$ & $\mathbf{M g}$ & $\mathbf{C u}$ & Others \\
\hline Phases of $\mathrm{Si}, \mathrm{Mg}, \mathrm{Cu}$ & 21.77 & 19.65 & 12.80 & Bal. \\
$\begin{array}{c}\text { Matrix phase in the } \\
\text { precipitation zone }\end{array}$ & 1.60 & 1.50 & 1.57 & Bal. \\
Matrix phase & 0.1 & $1.8 \sim 2.3$ & $2.0 \sim 2.6$ & Bal. \\
\hline
\end{tabular}

Bal. represents the mass fraction of $\mathrm{Al}$ and other trace elements.

Figure 5 is a transmission electron microscopic image of the microstructure of the composite material. The precipitation of nanoparticles with a size of about $90 \mathrm{~nm}$ was observed in the matrix. Further observation showed that there was an obvious dislocation accumulation on one side of the nanoparticles (yellow region), while the dislocation on the other side was relatively rare (red region). This was the result of nanoparticles hindering dislocation movement.

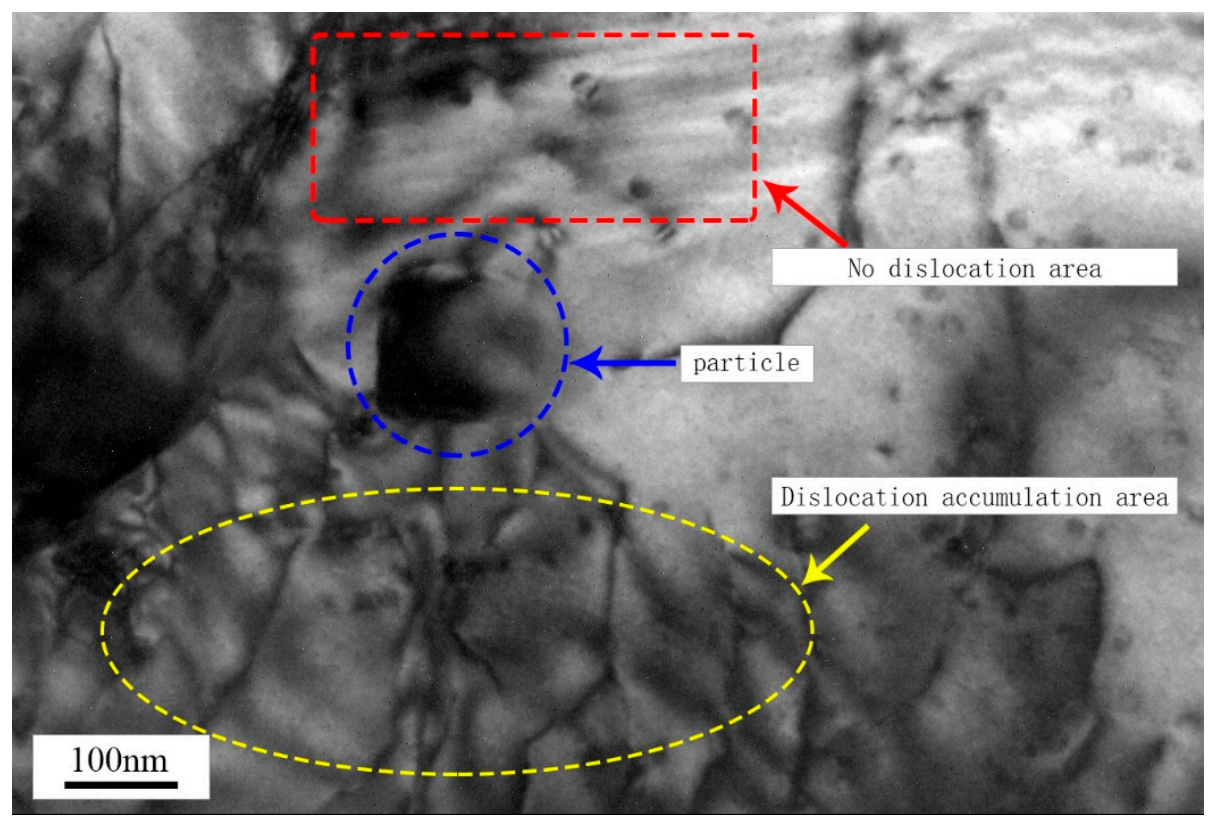

Figure 5. TEM photos of spray-deposited $\mathrm{SiCp} / 7055 \mathrm{Al}$ matrix composites.

\subsection{Mechanical Properties}

Table 5 shows the Vickers hardness of the composites. The hardness of the SiC particles and $\mathrm{Al}$ matrix was 10.20 HV0.05 and 8.44 HV0.05, respectively (see Table 5). From Figure 6, the hardness of the SiC particles was higher than that of the Al matrix, and it was hard and brittle. Generally, the hard particles in the material make it easy to cause a stress concentration and become the source of cracks. However, we observed that the SiC particles in the Al matrix were also able to hinder crack growth, which may be one of the reasons why $\mathrm{SiC}$ particles can be used as phase reinforcement, as shown in Figure 7.

Table 5. Vickers hardness of spray-deposited $\mathrm{SiC}_{\mathrm{p}} / 7055 \mathrm{Al}$ matrix composites.

\begin{tabular}{cc}
\hline Position & Hardness/HV \\
\hline Al matrix & 8.44 HV0.05 \\
SiC particle & 10.20 HV0.05 \\
\hline
\end{tabular}




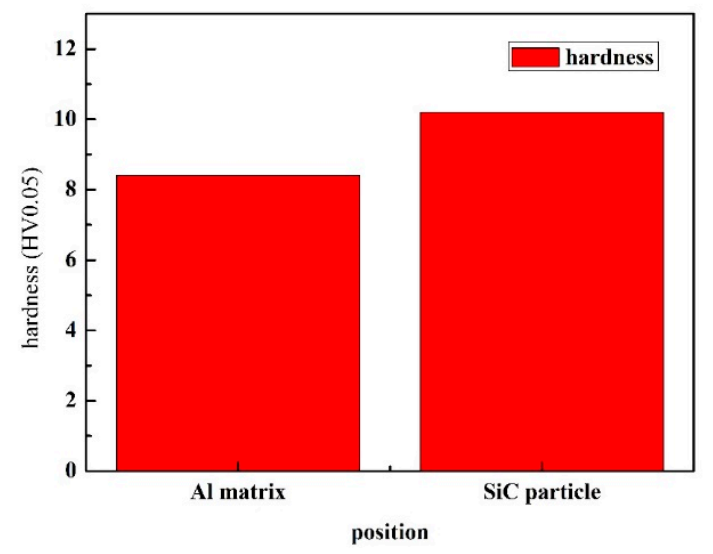

Figure 6. Matrix and $\mathrm{SiC}$ hardness tests of spray-deposited $\mathrm{SiC}_{\mathrm{p}} / 7055$ aluminum matrix composites.

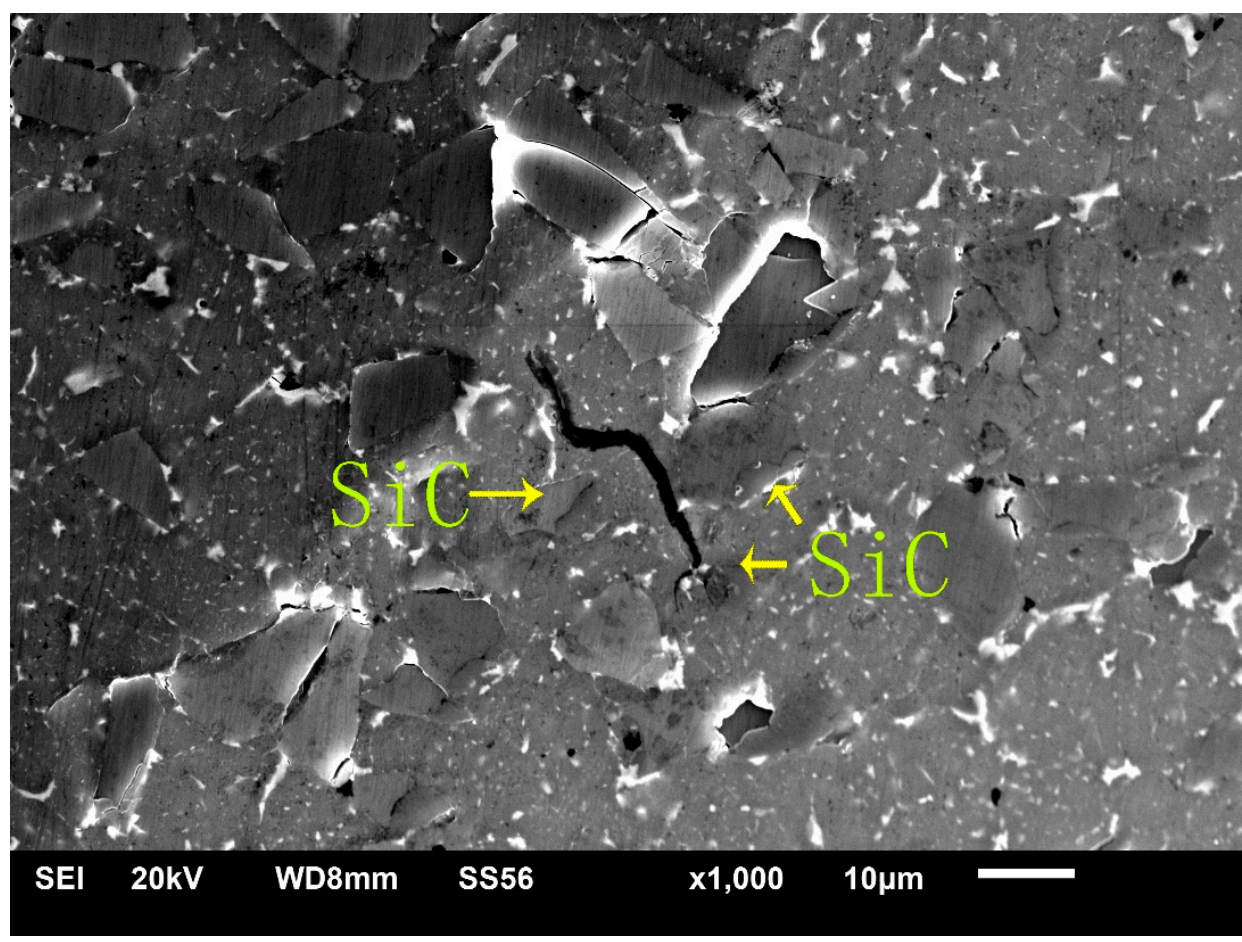

Figure 7. $\mathrm{SiC}$ particles in spray-deposited $\mathrm{SiC}_{\mathrm{p}} / 7055$ aluminum matrix composites prevent crack propagation.

\section{Conclusions}

(1) Spray-deposited $\mathrm{SiCp} / 7055 \mathrm{Al}$ matrix composites are mainly composed of alpha- $\mathrm{Al}, \mathrm{SiC}$, $\mathrm{Al}_{2} \mathrm{CuMg}, \mathrm{Al}_{2} \mathrm{Cu}$ and $\mathrm{MgZn}_{2}$. The aluminum liquid particle size of materials are different, and the phenomenon of large particles extruding small particles is common in the area surrounded by $\mathrm{SiC}$ particles, due to the asynchronization of nucleation caused by the different cooling rates of the $\mathrm{SiC}$ particles and the $\mathrm{Al}$ matrix.

(2) $\mathrm{C}$ and $\mathrm{Si}$ on the surface of $\mathrm{SiC}$ particles diffuse to the $\mathrm{Al}$ matrix. The distribution of the two elements followed the pattern of gradient weakening around the $\mathrm{SiC}$ particles-i.e., a ring-shaped enrichment zone of $\mathrm{C}$ and $\mathrm{Si}$ formed around the $\mathrm{SiC}$ particles-and a new enrichment zone of $\mathrm{Mg}$, $\mathrm{Si}$ and $\mathrm{Cu}$ formed in the closed area of the $\mathrm{SiC}$ particles.

(3) The $\mathrm{AlCu}$ and $\mathrm{AlMgCu}$ phases in the composites precipitated not only at the aluminum liquid particle boundaries, but also on the surface of the $\mathrm{SiC}$ particles, and had the characteristics of preferred nucleation. They tended to grow at the edges and corners of the SiC particles. 
(4) $\mathrm{SiC}$ particles can hinder the propagation of tear edges and cracks. Tearing edges and cracks will continue to propagate around $\mathrm{SiC}$ particles, which will increase their propagation journey and delay the fracture of materials.

(5) The mechanical properties of the composites in the radial direction are better than those in the axial direction. The tensile strength and elongation after fracture were $17.4 \%$ and $8 \%$ higher, respectively. The fracture morphology of the composites was mainly composed of cleavage platforms and a few dimples, generally of the brittle fracture type.

Author Contributions: Literature search, H.Y. and X.-q.J.; Figures, H.Y. and X.-w.S.; Study design, H.Y.; Data collection, H.Y., X.-w.S. and C.-m.L.; Data analysis, H.Y., X.-w.S., B.-b.T. and C.-m.L.; Data interpretation, H.Y. and X.-q.J.; Writing, H.Y. and X.-q.J.

Funding: This research was funded by the National Natural Science Foundation of China (51601153). Chongqing Research Program of Basic Research and Frontier Technology (cstc2017jcyjAX0195) and Chongqing Performance Incentive and Guidance Program of Scientific Research Institutions (cstc2018jxj150006) are gratefully acknowledged.

Conflicts of Interest: The authors declare no conflict of interest.

\section{References}

1. Chen, C.; Guo, L.; Luo, J.; Hao, J.; Guo, Z.; Volinsky, A.A. Aluminum powder size and microstructure effects on properties of boron nitride reinforced aluminum matrix composites fabricated by semi-solid powder metallurgy. Mater. Sci. Eng. A 2015, 646, 306-314. [CrossRef]

2. Sabbaghianrad, S.; Langdon, T.G. Developing superplasticity in an aluminum matrix composite processed by high-pressure torsion. Mater. Sci. Eng. A 2016, 655, 36-43. [CrossRef]

3. Zhao, S.-L. Research of Microstructure and Properties of Spray Formed High Alloyed High Speed Steel. Ph.D. Thesis, Shanghai University, Shanghai, China, 2017.

4. Guo, G.-D.; Liu, E.-Y.; Liu, F.; Yi, Z.-J.; Zhu, S.-H.; Ji, Z.-K. Preparation technology and prospect of particle reinforced magnesium matrix composites. Foundry Technol. 2018, 39, 2632-2636.

5. Su, Y.-Q.; Huang, X.-L.; Liu, X.-P. Microstructure \& properties of high silicon aluminum alloy by spray forming. Foundry Technol. 2018, 39, 2490-2493.

6. Li, H.-Z.; Kang, M.; Zhang, Y.; Niu, X.-F.; Liu, C.-H.; Jin, M.-F. Influences of jet parameters on structure and wear resistance of Ni-Co-BN(h) Nanocomposite Coatings. China Surf. Eng. 2018, 31, 103-112.

7. Zhang, X.-H.; Wang, Q. Research state of metal-matrix composites for electronic packaging. Micronanoelectron. Technol. 2018, 55, 18-25, 44.

8. Cao, Y.-P.; Dai, Z.-Q.; Liu, J.-T.; Ma, T.; Yang, G.-Y.; Li, Y.-G. Research progress and prospect of metal matrix composite materials. Foundry Technol. 2017, 38, 2319-2322.

9. Wang, W.-J.; Hong, Y.; Liu, J.-Q.; Wu, Y.-C. Effect of SiC particle size distribution on the microstructure and properties of $\mathrm{SiC}_{\mathrm{p}} / \mathrm{Al}$ composites. Chin. J. Nonferr. Met. 2018, 28, 2523-2530.

10. Huo, S.-Y.; Xie, L.-J.; Xiang, J.-F.; Pang, S.-Q. Research progress on ultra-precision machining of silicon carbide and its particle-reinforced aluminum matrix composites. Tool Eng. 2018, 52, 3-12.

11. Liu, H.-B.; Yang, S.-L.; Xie, C.-J.; Zhang, Q.; Cao, Y. Research development of joining of SiC particle reinforced Al-based composite. Electr. Weld. Mach. 2018, 48, 94-98.

12. Wang, K.; Jiang, R.-P.; Zhang, L.-H.; Li, R.-Q.; Li, X.-Q. Effect of ultrasonic field on particle distribution and hardness of SiCp/7085 composites. J. Cent. South Univ. (Sci. Technol.) 2018, 49, 529-535.

13. El-Kady, O.; Fathy, A. Effect of SiC particle size on the physical and mechanical properties of extruded Al matrix nanocomposites. Mater. Des. 2014, 54, 348-353. [CrossRef]

14. Wu, G.-H.; Wang, X.; Jiang, L.-T.; Ma, B.-R. A nanostructural design to produce high ductility of high volume fraction SiCp/Al composites with enhanced strength. Mater. Des. 2014, 61, 141-145. [CrossRef]

15. Park, J.K.; Lucas, J.P. Moisture effect on SiCp/6061 Al MMC: Dissolution of interfacial $\mathrm{Al}_{4} \mathrm{C}_{3}$. Scr. Mater. 1997, 37, 511-516. [CrossRef]

16. Su, B.; Yan, H.G.; Chen, G.; Shi, J.L.; Chen, J.H.; Zeng, P.L. Study on the preparation of the SiCp/Al-20Si-3Cu functionally graded material using spray deposition. Mater. Sci. Eng. A 2010, 527, 6660-6665. [CrossRef] 
17. Yang, Y.-Y.; Wei, X.-C.; Hong, X.-L.; Wang, W.-R.; Ouyang, Q.-B.; Gu, H.-L.; Feng, Q. Dry friction coefficient of high content $\mathrm{SiC}$ particle reinforced aluminum matrix composite against commercial friction material. J. Tribol. 2014, 34, 446-451.

18. Zhang, X.-Z.; Zhao, S.-T.; Liu, G.-W.; Xu, Z.-W.; Shao, H.-C.; Qiao, G.-J. Review on brazing of high volume faction $\mathrm{SiC}_{\mathrm{p}} / \mathrm{Al}$ composites for electronic packaging applications. Rare Met. Mater. Eng. 2017, 46, 2812-2819.

19. Yang, Y. Research on Preparation of Multilayer of SiC/Al Electronic Packaging Part by Using Semi-Soliddie Forging and Bonding Integration. Master's Thesis, Harbin Institute of Technology, Harbin, China, 2017.

20. Gao, Z.; Cheng, D.-F.; Wang, P.; Niu, J.-T. Friction stir welding of packaging container made of $\mathrm{SiC}_{\mathrm{p}} / \mathrm{Al}$ compositeswith low volume fraction. Bull. Chin. Ceram. Soc. 2017, 36, 1735-1739.

21. Luo, W.-Q. Surface Metallization, Wetting and Brazing of $\mathrm{SiC}_{\mathrm{p}} / \mathrm{Al}$ Composites for Electronic Packaging. Master's Thesis, Jiangsu University, Zhenjiang, China, 2017.

22. Cai, S.; Chen, T.; Li, P.; Zhang, X. Microstructure and properties of $\mathrm{SiC}_{\mathrm{p}} / \mathrm{Al}$ Electronic packaging materials fabricated by thixoforming. Spec. Cast. Nonferr. Alloy. 2016, 36, 945-949.

23. Zhang, C.-C. The Research on the Microstructure and Mechanical Properties of Spray Co-Deposited $7090 / \mathrm{SiC}_{\mathrm{p}}$ Composites. Master's Thesis, Hunan University, Changsha, China, 2008.

24. $\mathrm{Xu}, \mathrm{H}$.-Y. The Research on $7075 / \mathrm{SiC}_{\mathrm{p}}$ Composite Sheets' Produetion Process. Master's Thesis, Hunan University, Changsha, China, 2004.

25. Zhang, C.-C.; Yuan, W.-H. Effect of heat-treatment on fracture toughness of spray deposition $7090 / \mathrm{SiC}_{\mathrm{p}}$ composites. Mater. Rev. 2013, 27, 31-34.

26. Frank Su, Y.H.; Chen, Y.C.; Tsao, C.Y.A. Workability of spray-formde $7075 \mathrm{Al}$ alloy reinforced with $\mathrm{SiC}_{\mathrm{p}}$ at elevated temperatures. Mater. Sci. Eng. 2004, 364, 296-304.

27. Ji, Z.; Xi, J.-H.; Wang, Y.-Q.; Cui, Y.-L.; Yuan, W.-H. Effect of particle distribution on mechanical properties of multi-layer spray forming 7075/SiC $\mathrm{p}_{\mathrm{p}}$ composites after hot forming. Powder Metall. Technol. 2009, 27, $268-272$.

28. Sun, Y.-P.; Yan, H.-G.; He, J.-M.; Chen, G. Microstructure and mechanical properties of spray co-deposition $\mathrm{SiC}_{\mathrm{p}} / 7090 \mathrm{Al}$ composite after solution treatment. Heat Treat. Met. 2011, 36, 60-64.

29. Sun, Y.-P.; Yan, H.-G.; Chen, Z.-H.; Chen, G. Microstructures and properties of heat-treated $7090 / \mathrm{SiC}_{\mathrm{p}}$ aluminum matrix composite. Chin. J. Nonferr. Met. 2008, 18, 829-833.

30. Jiang, Z.; Qin, Y. Study on Microstructure and Mechanical Properties of SiC/Al-Fe-V-Si Composite Materials by Spray Deposition. Hot Work. Technol. 2017, 46, 118-120.

31. Chen, X.; Yang, C.; Guan, L.; Yan, B. $\mathrm{TiB}_{2} / \mathrm{Al}_{2} \mathrm{O}_{3}$ ceramic particle reinforced aluminum fabricated by spray deposition. Mater. Sci. Eng. A 2008, 496, 52-58.

32. Li, W.; Chen, Z.H.; Chen, D.; Teng, J.; Fan, C. Low-cycle fatigue behavior of SiCp/Al-Si composites produced by spray deposition. Mater. Sci. Eng. A 2010, 527, 7631-7637. [CrossRef]

33. Yu, H.; Wang, M.; Jia, Y.; Xiao, Z.; Chen, C.; Lei, Q.; Li, Z.; Chen, W.; Zhang, H.; Wang, Y.; et al. High strength and large ductility in spray-deposited Al-Zn-Mg-Cu alloys. J. Alloy. Compd. 2014, 601, 120-125. [CrossRef]

34. Guo, B.; Ge, C.-C.; Xu, Y. Flow Behavior and Numerical Simulation of Spray-Formed FGH95 Superalloy under Hot Compression. J. Iron Steel Res. (Int.) 2013, 20, 69-74. [CrossRef]

35. He, Y.; Tu, H.; Qiao, B.; Feng, L.; Yang, J.; Sun, Y. Tensile fracture behavior of spray-deposited SiC $\mathrm{P} / \mathrm{Al}-\mathrm{Fe}-\mathrm{V}-\mathrm{Si}$ composite sheet. Adv. Compos. Mater. 2013, 22, 227-237. [CrossRef]

36. Li, X. Study on Microstructure and Mechanical Properties of 7055 Aluminum Alloys by Spray Forming. Mster's Thesis, Shanghai Jiao Tong University, Shanghai, China, 2008.

37. Yang, S. The Behaviour of Compression Deformation and Forging Technology of Spray Deposited $7075 / \mathrm{SiC}_{\mathrm{p}}$ Composite. Master's Thesis, Hunan University, Changsha, China, 2005.

38. Lee, J.-C.; Seok, H.-K.; Lee, H.-I. Alloy design of thixoformable wrought SiC/Al alloy composites. Mater. Res. Bull. 1999, 34, 35-42. [CrossRef]

(C) 2019 by the authors. Licensee MDPI, Basel, Switzerland. This article is an open access article distributed under the terms and conditions of the Creative Commons Attribution (CC BY) license (http://creativecommons.org/licenses/by/4.0/). 